\title{
Pay or Display: Monetary Sanctions and the Performance of Accountability and Procedural Integrity in New York and Illinois Courts
}

\author{
KARIN D. MARTIN®，KIMBERLY SPENCER-SUAREZ，AND \\ GABRIELA KIRK(D)
}

This article proposes the centrality of procedural integrity - or fidelity to local norms of case processing-to the post-sentencing adjudication of monetary sanctions. We draw on insights gained from observations of more than 4,200 criminal cases in sixteen courts in New York and Illinois and find that procedural integrity becomes a focal point in the absence of monetary sanctions paid in full and on time. This examination of the interplay between the sociolegal context and workgroups within courtrooms brings to light how case processing pressure, mandatory monetary sanctions, defendants with pronounced financial insecurity, and judicial discretion inform the role monetary sanctions play in court operations.

Keywords: monetary sanctions, surcharges, case processing, courts

As state legislatures have dramatically expanded monetary punishment, establishing new fines and fees and increasing the dollar amount of those already on the books, implementation is left to the courts. Yet, because defendants are seldom able to pay these sanctions promptly and in full, the courts must adapt their practices to managing the tension between these policy mandates and defendants' material realities. In the New York and Illinois court systems, the performance of accountabil- ity dominates the assessment, administration, and collection of monetary sanctions. Practices in both jurisdictions emphasize how much time is needed for payment rather than willfulness or inability to pay. Moreover, in each state-regardless of whether the court handles infractions, misdemeanors, or felonies-a substantial amount of time is spent on frequent but brief appearances related to ongoing payment of outstanding debt by defendants and the scheduling of subsequent hearings. This

Karin D. Martin is assistant professor at the Daniel J. Evans School of Public Policy and Governance at the University of Washington, United States. Kimberly Spencer-Suarez is a doctoral candidate at the Columbia School of Social Work, United States. Gabriela Kirk is a doctoral candidate in the Department of Sociology at Northwestern University, United States.

(C) 2022 Russell Sage Foundation. Martin, Karin D., Kimberly Spencer-Suarez, and Gabriela Kirk. 2022. “Pay or Display: Monetary Sanctions and the Performance of Accountability and Procedural Integrity in New York and Illinois Courts." RSF: The Russell Sage Foundation Journal of the Social Sciences 8(1): 128-47. DOI: 10.7758/RSF 2022.8.1.06. This research was funded by a grant to the University of Washington from the Laura and John Arnold Foundation (Alexes Harris, PI). We thank the faculty and graduate student collaborators of the Multi-State Study of Monetary Sanctions for their intellectual contributions to the project. Special thanks to Barbara Talkington and Aaron Nordman for their excellent research assistance. Direct correspondence to: Karin Martin, at kdmartin@uw.edu, Box 353055 Seattle WA 98105-6605, United States.

Open Access Policy: RSF: The Russell Sage Foundation Journal of the Social Sciences is an open access journal. This article is published under a Creative Commons Attribution-NonCommercial-NoDerivs 3.0 Unported License. 
dynamic, in which often-recurring appearances and small payments serve as ways defendants can (and are often expected to) engender leniency and forestall escalating consequences, is a core feature of the processing of monetary sanctions in these two states (see also Pattillo and Kirk 2021; Cadigan and Kirk 2020). Mary Pattillo and Gabriela Kirk (2021) find that this manipulation of one's time when it comes to paying back court debt leads to a form of "layaway freedom" and coercive financialization, punishing beyond simply the financial burden. Here, we explore what factors, other than the desire to punish, lead courts to engage in collection practices that extract considerable time not only from defendants but also from the court. We find that the cardinal priority is the display of procedural integrity-or fidelity to local norms of case processing-rather than transparency or efficiency of case processing being guiding principles.

To explore these dynamics of accountability performance and procedural integrity, we draw on ethnographic observations of court proceedings and interviews with court actors in a variety of courtrooms across Illinois and New York, collected as part of the broader MultiState Study of Monetary Sanctions. These data provide particular insights into practices surrounding post-conviction collection of monetary sanctions (legal financial obligations, or LFOs) and how court actors justify the time demands these practices place on the system, often with little success in actual financial collection due to the lack of consideration for defendants' ability to pay. Insights from several literatures provide a framework for analyzing our data. Jeffery Ulmer's (2019) construction of courts as "inhabited institutions" takes into consideration the sociolegal context in which courts operate, at the same time accounting for the agentic capacities, relationships, and perspectives of the individual actors who enact the courts' quotidian functions. Centering organizational culture in the analysis of sentencing and other judicial decisions helps clarify how criminal justice policy is actually implemented. Empirical and theoretical work on the concepts of leniency and compliance shed light on the dynamic between the defendant and court actors.
How the court's authority interacts with the defendant's assent to that authority is the fulcrum of our analysis, yet whereas the literature primarily concerns sentencing, we focus on the post-sentencing stage. This analysis centers on three dimensions of the courts' approaches to administering monetary punishment after cases have been adjudicated. First, we find that case processing is defined by statutory constraints on judicial discretion in the sentencing of monetary sanctions. Judges in Illinois and New York cannot forgo imposing mandatory monetary sanctions, even though doing so results in the courts' protracted management of indigent defendants' debt obligations, thereby undermining efficient case disposition and exacerbating the problem of high caseloads. Second, we examine how interpersonal dynamics guide post-adjudication handling of monetary sanctions. Through their everyday interactions, courtroom workgroups construct localized norms and routines, which then determine how the court will handle most of the cases that come before it. Common types of charges generally correspond to typical penalties, or "going rates," though we extend this concept to encompass the ways in which courts account for time in the enforcement of monetary sanctions. Our analysis indicates that payment plans and extensions are an important mechanism through which courts exercise discretion over monetary sanctions enforcement.

Third and finally, we find that salient aspects of nonpayment and its consequences entail direct negotiations between judges and defendants and the enactment of compliance "rituals" (Huebner and Shannon 2022, this volume). Unable to expeditiously enforce monetary sanctions, the courts compel defendants to engage in drawn-out performances of accountability, including repeated appearances to make small payments and displays of deference and contrition. These performative scripts function as an avenue through which courts navigate statutory requirements that are at odds with defendants' financial capacities, thereby upholding what we refer to as procedural integrity.

\section{CONCEPTUAL FRAMEWORK}

Our conceptual framework brings together insights from several lines of literature that ad- 
dress how courts function, factors influencing decision-makers working in courts, and the demands courts place on defendants.

\section{Inhabited Institutions}

Ulmer's (2019) concept of courts as inhabited institutions draws on insights from organizational sociology to propose that those who participate in court (judges, attorneys, defendants, among others) create the culture of a court and enact the implementation of criminal justice policy. In this framing, broader legal constraints inform but do not wholly dictate what transpires on a day-to-day basis in a courtroom. Instead, the institution of court and the individuals working in it are mutually influential. At the heart of Ulmer's thesis is the realization that people working in courts have agency, which drives behavior and interactions, thereby creating organizational culture. An important implication of this insight is that clarity about the "interactions that jointly produce discretionary decisions" $(2019,485)$ may be more useful than attempting to parse the specifics of discretion exercised by, for example, judges versus prosecutors. The underlying question is how court actors constantly navigate the terrain where formal rules and laws meet informal norms and shared perceptions.

In Ulmer's conception, contested space frequently exists between formal and informal constraints on decisions in the courtroom. He explains that "macro myths and their categorical rules are often at odds with organizational realities, with competing interests, or with the contextual circumstances and constraints. The result is localized adaptation and selective circumvention of formalized rules and structures of control" $(2019,488)$. In the case of postsentencing adjudication of monetary sanctions payment, the pertinent macro myth may be "equality and uniformity before the law," meaning that people have a responsibility to pay what they owe-be it for deterrence, revenueraising, or both. However, courts also have an interest in minimizing case processing time at the same time that dockets are often filled with people without enough funds to fulfill their monetary obligations. Situating monetary sanctions in the framework of courts as inhabited institutions thus raises the question of how external factors interact with courtroom decision-making in the confrontation of unpaid court-ordered debt as an individual reality. In our analysis, this interaction engenders a commitment to procedural integrity, wherein court actors cocreate and adhere to the local norms of managing time and payment related to monetary sanctions.

The crux of the court as an inhabited institution is the workgroup (Ulmer 2019). In essence, interactions among court actors, day in and day out, are what yield case outcomes. Judges, attorneys, and other court actors cocreate criminal sentences by interpreting the law and negotiating (Ulmer 2012; Kim, Spohn, and Hedberg 2015). Importantly, no sentencing decision is a one-off. Likewise, the workgroup is not static, but instead in a continual state of development. Through this ongoing coproduction, the workgroup's going rate for appropriate sentences for typical offenses is established (Eisenstein, Fleming, and Nardulli 1988). The going rate is defined as the typical punishment for a typical crime in a given courtroom, often locally determined. A similar construct exists in Malcolm Feeley's (1979) idea of case worth, in which workgroup members mobilize facts about the defendant and the case, framing them in a certain way that ends up significantly affecting the subsequent plea deal. In terms of procedural integrity, the concepts of going rate and case worth suggest that the courtroom workgroup will establish locally acceptable parameters for managing on-going payments and related court appearances.

The notion of a going rate in sentencing is useful for illuminating the routinization aspect of adjudicating monetary sanctions. Indeed, Tyler Smith, Christina Thompson, and Michele Cadigan (2022, this volume) leverage this concept to explicate how the localized norms allow attorneys to anticipate the responses of other court actors, especially judges. These norms also allow attorneys to modulate their adversarial strategies accordingly, shaping the sensemaking processes through which these actors collaboratively interpret and implement monetary sanction reform measures handed down by state legislatures. In their day-to-day functions, courtroom workgroups often use going rates as a cognitive template for how to pro- 
ceed with a case (see Ulmer 2019). For example, plea bargains may fall into patterns of standardized sentences for crimes the court sees regularly, particularly those it sees frequently (Lynch 2019; see also Sudnow 1965). However, when it comes to decision-making in the allocation of permissible time in the enforcement of paying monetary sanctions, the idea of a going rate has notable limits. On the one hand, the analog in terms of judges determining an acceptable amount of time to pay is clear. The amount of time defendants are given is significant, given that court actors in Illinois and New York often have little discretion in the dollar amount and no formal systems to consider individual circumstances, often known as abilityto-pay determinations. Yet judges do have the authority and discretion to impose constraints on payment as well as consequences for nonpayment. On the other hand, the nature of postsentencing management excludes from the proceedings much of the courtroom workgroup that would otherwise play a role in determining the going rate. Instead, decisions about minimum payment amounts and how long a person has to pay are typically a result of negotiations between the judge and the defendant.

The focal concerns concept encapsulates the idea that individual decision-making occurs in a particular context of commonly understood norms. That is, each courtroom has its own organizational culture with its own local norms, existing in a broader institutional context. Early work proposes that cognitive shortcuts and biases such as heuristics or stereotypes influence the assessment of the three focal concerns of blameworthiness, protection of the community, and practical constraints (Steffensmeier, Ulmer, and Kramer 1998). Several practical concerns and aspects of blameworthiness are particularly relevant to protracted monetary sanction payment. When a person is making repeated court appearances related to monetary sanctions, the judge must make administrative decisions about scheduling, payment plans, and dollar amounts while assessing the defendant's compliance with the court's previous orders. The norms surrounding both the pace and frequency of court appearances as well as what makes a defendant deserving of punitive action or leniency constitute focal con- cerns. Thus the concept of focal concerns provides a basis for interpreting decision-making related to monetary sanctions and opens new lines of inquiry into this topic. In particular, it is helpful in understanding how fidelity to local norms of case processing (procedural integrity) occurs.

The concepts of courtroom workgroups, going rates, and focal concerns in concert provide a useful foundation for the study of how monetary sanction payment is managed. Moreover, by applying these concepts to a noncustodial sentence, we expand and deepen the literature in useful ways. First, courtroom workgroups help explain how monetary sanction sentences are determined and what local shared norms are. For instance, workgroups influence the use and amount of discretionary fines. However, the relevance of courtroom workgroups may be diminished when post-sentencing payment is negotiated between the judge and the defendant. The determination of a payment plan can involve only the judge and the defendant rather than the entire workgroup. We can thus observe what happens when the courtroom workgroup shifts to include the defendant in a limited way. Second, the idea of a going rate for sentencing is useful in describing typical processes related to monetary sanctions. Going rates may set informal parameters for the types of monetary sanctions assessed or payment amounts. Our data allow us to investigate the applicability of going rates when what is at stake is time to pay as opposed to whether or how much to pay. Third, this analysis goes beyond the typical use of focal concerns as an explanation of inequalities in sentencing outcomes. Instead, we use the concept as a point of departure for interrogating the interplay between context and individual decision-making in the sphere of monetary sanctions. Together, these concepts provide useful building blocks for understanding the origination and function of procedural integrity.

\section{Performative Aspects of Compliance}

The ways in which courtroom participants enact performative scripts of accountability are key to developing a holistic understanding of what transpires during a court session. Central elements include the actions and affect of de- 
fendants, who are obliged to demonstrate a degree of deference in order to maintain good standing with the court. They must undergo the "procedural hassle" of continual hearings and the attendant opportunity costs (childcare, lost wages, and so on), while abiding the courtroom's strict rules and customs - sitting quietly and attentively and waiting for long periods, sometimes amid confusion and "enforced ignorance" about the status of one's case (KohlerHausmann 2018; see also Slavinski and SpencerSuarez 2021). Not only must defendants adhere to court orders, their presentation inside the courtroom is also subjected to scrutiny. As Issa Kohler-Hausmann notes, "Court actors react to how defendants perform under procedural hassle not only because that performance might proxy general law-abiding character, but also because they interpret the performance as a meaningful demonstration of who the defendant is and therefore what he deserves" (2018, 230). Beth Huebner and Andrea Giuffre's (2022, this volume) examination of monetary punishment in St. Louis, Missouri, with its fragmented patchwork of relatively autonomous municipal courts, highlights just how onerous these requirements can be (see also Huebner and Shannon 2022, this volume). They find that many defendants, unrepresented by counsel and inadequately informed about their cases, are unequipped to shepherd themselves through the legal process. Yet, because most cannot pay off their encumbrances, their cases drag on and on. It is perhaps unsurprising then that some simply give up and cease their efforts to comply. Conversely, defendants who persist through the gauntlet of hearings and court mandates are effectively exhibiting personal accountability to the court. This tends to engender leniency on the part of judges and other relevant authorities, perhaps leading to a more favorable outcome in their case. Defendants' consistency and scrupulous comportment in court appearances may be especially important signifiers of deference to the court, and certainly more so than monetary sanctions payment, given that many defendants are unable rather than unwilling to comply with legal financial obligations.

To a large extent, the performance of accountability plays out in the interactional dy- namics in the courtroom, of which affect is an important constituent element. During criminal proceedings, the various actors' demeanors and feeling states, particularly those of defendants, can prove highly consequential. Contrition presents a notable example, one particularly relevant to the performance of deference. Substantial evidence indicates that evaluations of defendant remorse play a key role in sentencing and parole decisions, as do determinations about whether to try a minor as an adult, and forensic assessments (Bandes 2016b; Wood and MacMartin 2007). Remorse is also an explicit evaluative criterion for juries in capital cases (Bandes 2016a), thus being grounds for literal life-or-death decisions. Work on the assessment and impact of contrition in front-end criminal legal processes focuses on the sentencing context (see, for example, Wood and MacMartin 2007). It is clear that expressions of remorse may induce some measure of leniency on the part of jurors or judges. As Jeffrey Rachlinski, Chris Guthrie, and Andrew Wistrich note, "Apologies are intended to convince the recipient that the transgressor's actions reflect a less malevolent mental state or that the transgressor's long-term proclivities are not as destructive as his or her exhibited behavior would suggest. A successful apology restores at least some of a transgressor's status as a trustworthy individual" $(2013,1195)$. When decision-makers see contrition as genuine, it can attenuate perceptions of the defendant's blameworthiness (Steffensmeier, Ulmer, and Kramer 1998). Taken together, the literature on courts as an inhabited institution, the concepts of a going rate for criminal sentences and the focal concerns of a court workgroups, and foregrounding the performative aspect of compliance lay the groundwork for our attention in this analysis to procedural integrity.

Procedural integrity refers to a fidelity to process that may eclipse other concerns. Judges are obliged to implement criminal justice policy through their interpretation of the law. The law may constrain sentencing options but not the details of how court proceeds on a daily basis. Instead, the court workgroups cocreate a culture in which the parameters of acceptable sentences and consequences for nonpayment are largely settled. The stability of 
such decisions goes hand in hand with the approach to case processing in any given court. In the case of post-sentencing adjudication of monetary sanctions, the connection between the two manifests as a routinization of repeated court appearances for nonpayment that shows little variation in outcomes. The importance of the act of coming to court seems to overshadow what transpires during court. Maintaining constancy of the court process looms large.

Using procedural integrity as a lens through which to understand our data helps clarify the role of case processing concerns in court actors' decision-making. The concept of procedural integrity synthesizes aspects of inhabited institutions, focal concerns, and going rates to capture a phenomenon specific to the handling of monetary sanctions in our two sites. The data we bring to bear on this question can advance the literature by emphasizing the "interpretation, culture, and processes" surrounding the adjudication of monetary sanctions (Ulmer $2019,485)$. By offering insight on how interactions reflect discretion around the pay or display issue, we deepen current understanding of the nexus of court processes and monetary sanctions. We find that statutory constraints, concern with efficiency, caseload, and speed of hearings all emerge as significant factors. Our data illuminate how workgroups, the going rate, and procedural integrity are all mutually reinforcing. Finally, our findings reveal that negotiation in the judge-defendant dyad, minimal sporadic payments, and the performativity around time as punishment are all significant to the post-sentencing adjudication of monetary sanctions.

\section{CASE DESCRIPTION}

Illinois and New York are two of eight states studied as part of the Multi-State Study of Monetary Sanctions (Harris, Pattillo, and Sykes 2022, this volume). In this work, the authors note several structural similarities in court proceedings between these two states in particular that motivated this comparison and analysis. However, the two states operate remarkably different court systems, with different levels of jurisdiction, that led to differences in our data collection strategies.
Illinois

Illinois criminal courts are characterized by a single unified, county-level court system and a recent history of reform in the domain of monetary sanctions. Each of the 102 counties in Illinois has its own court system, the largest of which-Cook-includes the city of Chicago and numerous courthouses; many smaller counties host only a single courtroom.

We conducted interviews with court personnel and observations of court hearings in seven counties spread across Illinois (downstate, midstate, and the Chicago metro area). We spent time in both suburban and city courthouses in Cook County. The remaining counties were one in the suburban Chicago metro area, two adjacent in the midstate (one home to a small city), and three adjacent small rural counties downstate. We focused our observations on Cook County courtrooms that were likely to discuss monetary sanctions such as traffic cases, misdemeanor cases, and status hearings for felony cases. In the smaller counties we often observed the entire court call for a given day.

Many cases were hearings regarding outstanding debt and typically lasted between three and five minutes, sometimes less. This was largely true both for the busiest traffic courtrooms in Chicago and for the small one room rural courthouses. Across the counties we observed, little consideration was given to ability to pay; these conversations typically involved a quick update as to whether a payment had been made, how much time was needed, and when the next court hearing would be.

\section{New York}

New York courts are organized on the basis of geography, case type (housing, families, and so on), and whether an offense is a felony or a misdemeanor. The court system has three levels and is divided geographically into four judicial departments and thirteen judicial districts. New York City is unique in the state. The Criminal Court of the City of New York handles misdemeanors and lesser offenses. Outside New York City are district courts (six), city courts, town and village justice courts, and county courts (located in each county outside New York City). Outside New York City, felony 
trials only take place in county courts. In addition to observing cases in the Criminal Court of the City of New York and the Bronx Criminal Court, we conducted observations in two county courts, two city courts and three town and village justice courts. New York courts handle more than four million cases a year. Town and village justice courts are important to the discussion of monetary sanctions because they number almost 1,300 , are presided over by 2,200 judges, and handle about two million cases a year. These courts hear both civil (small claims, landlord-tenant) and criminal matters (misdemeanors and violations, as well as arraignments for felonies). They exist everywhere in the state except for New York City and are often run by part-time judges and clerks. Approximately two-thirds of the town and village court judges do not have a law degree.

Courts in New York have "parts" or specific courtrooms that handle a particular type of case. We observed evidence of uniformity on some aspects of courts around the state. For one, the frequency of observing cases involving monetary sanctions varied significantly depending on the part. Some days, very few or none of the cases involved monetary sanctions; other days, almost every case did. The role of the bailiffs and clerks appeared to be standardized across the state. Clerks exerted no authority over the imposition, administration, or collection of monetary sanctions beyond filling in and filing the necessary paperwork. Bailiffs in all the courtrooms played a role in checking people in as they arrived at court. Courts around the state were busiest in the morning, but routinely began anywhere from five to thirty minutes after the posted start time. Court business typically concluded in the early afternoon and courthouses were nearly entirely empty on Fridays. Many cases were hearings related to unpaid debt, typically lasting less than five minutes, often less than two minutes. We observed little explicit consideration of ability to pay. Exchanges between the judge and defendant typically involved a quick update as to whether a payment had been made, how much additional time was needed, and when the next court hearing would be.

\section{Commonalities Across Sites}

Our experience was that researcher anonymity was impossible in the courts we observed, so we often did not pursue it because of our notetaking while in court and because we were often recruiting court actors for interviews. Court security tended to remember the researchers within two or three visits. Nearly without exception, if one of us was present when the docket was complete, we would end up being addressed or summoned by the judge. But defense counsel, prosecutors, and court security all - at various times on their own initiativeintroduced themselves, asked us about what we were doing, and then introduced us to the judge. Sometimes the judge was curious about us while court was in session and once even summoned one of us to the bench during the proceedings. In neither site were the bailiff or clerks involved in the process of monetary sanctions other than completing paperwork, checking people in, and managing the behavior of defendants. In many post-adjudication hearings and lower-level misdemeanors or traffic cases in both New York and Illinois, defendants did not have attorneys. Ultimately discussions involved the state's attorney (prosecutor), the judge, and the defendant.

Despite some structural differences, the two sites had a number of similarities relevant to the adjudication of monetary sanctions. Both Illinois and New York are slow to impose jail time or other punitive consequences for nonpayment, instead scheduling additional postconviction hearings to draw out the length of time for payment. Both have post-conviction in-person hearings, typically in the absence of legal representation for the defendant. This process of a judge and a defendant having repeated contact in order to discuss unpaid monetary sanctions affords an opportunity to examine both interpersonal dynamics and legal outcomes. As a result, we are able to observe a type of court proceeding that is common yet specific to monetary sanctions and therefore offers insights into how those involved navigate the interplay between institutional and hyperlocal forces. Unlike states where clerks may play an administrative role in this process, judges in these hearings hold all of the discretion surrounding repayment. 
Table 1. Illinois and New York Interview Participants

\begin{tabular}{lcccccc}
\hline & Judge & Prosecutor & $\begin{array}{c}\text { Defense } \\
\text { Attorney }\end{array}$ & $\begin{array}{c}\text { Probation } \\
\text { Officer }\end{array}$ & Clerk & $\begin{array}{c}\text { Total by } \\
\text { State }\end{array}$ \\
\hline IL & 28 & 18 & 20 & 8 & 13 & 87 \\
NY & 12 & 4 & 19 & 0 & 9 & 44 \\
Total by & 40 & 22 & 39 & 8 & 22 & 131 \\
Category & & & & & & \\
\hline
\end{tabular}

Source: Author's calculations

Further, both Illinois and New York have a system of monetary sanctions dominated by mandatory surcharges, fines being much less prominent than at other sites in the larger study (see Harris, Pattillo, and Sykes 2022, this volume). Finally, although the differences between rural and urban courts were notable across a number of states, we observed comparable features in both Illinois and New York-such as the stability of the courtroom workgroups in both large and small courthouses and the tendency for rural court professionals to draw contrasts between their own courts and urban ones.

\section{DATA AND METHODS}

In Illinois, we observed 2,036 unique cases during the study period. Monetary sanctions were discussed in some way in 716, about one-third. Our analysis draws on ethnographic data from 241 hours of courtroom observations and interviews with eighty-seven court actors in Illinois, consisting of twenty-eight judges, eighteen prosecutors, twenty defense attorneys, thirteen clerks, and eight probation officers. In New York, we observed 2240 cases, approximately one-third involving monetary sanctions. The New York data represent 252 hours of courtroom observations and interviews with fifteen judges, four prosecutors, sixteen defense attorneys, and nine clerks (see table 1 ). We recruited these participants by approaching them in their courtrooms following courtroom observations or in-person visits to their offices. Data collection occurred between 2016 and 2018 (for a more detailed discussion of recruitment, collection, and analysis strategies, see Harris, Pattillo, and Sykes 2022, this volume).

We discussed several initial themes based on recollections of the data. Initial explorations of the interview and ethnographic data suggested a number of potentially fruitful topics to probe more deeply. We ultimately decided to explore the role of repeated court appearances, contrition, minimal sporadic payments, leniency, performances of accountability, and the role of time generally.

Using the master codebook for the broader project, we focused on a subset of codes related to these themes. We reviewed the following codes in the ethnographic data: appearance, comportment; indigency; waiving, reducing; payment plans; making, not making payment; explanations for nonpayment; compliancenoncompliance; case processing; reprimand and accountability; and leniency. We focused on payment plans; making, not making payment; and compliance-noncompliance. We also used the master codebook for the decisionmaker interviews and focused on the following codes: waiving or suspending LFOs, alternatives to payments, monitoring LFO payments, stay continuance or reschedule, postconviction hearings, purpose of LFOs, system strain and efficiency, discretion, and debtor motivation. After pulling the relevant data from these codes, we then wrote and exchanged several rounds of analytic and descriptive memos summarizing these data. Through this iterative process, we arrived at a set of themes with strong empirical support.

\section{FINDINGS}

In keeping with Ulmer's notion of courts as inhabited institutions, we organize our findings into those related to aspects of the sociolegal context of the courts as well as the specifics of what transpires in the courtroom. 


\section{Case Processing}

Case processing emerged as a focal point in both study sites. Our data show how judges, in particular, navigate the external pressure imposed by legislation coupled with large caseloads and protracted efforts to induce payment of monetary sanctions.

\section{Statutory Constraints}

In both Illinois and New York, mandatory surcharges and assessments dominate the domain of monetary sanctions. In Illinois at the time of our research, the state used a complicated and byzantine system of fines and fees largely determined by statute. Ninety-six unique statutory entries pertained to monetary sanctions (Friedman and Pattillo 2019). These compilations of fines and fees are disbursed to various agencies, government bodies, special funds, and the state's general fund. Speaking with court actors in Illinois made it clear that they often forwent imposing discretionary fines because the amounts of mandatory fines and fees had so increased in the previous decade. Despite being delineated by statute, each county often had different interpretations of the statutes or were missing certain fines or fees, resulting in variation across jurisdictions. In New York, a mandatory surcharge is imposed for every violation (\$95), misdemeanor (\$175), and felony (\$300). What is known as a Crime Victim Assessment fee (\$25) applies to all offenses and a DNA Databank fee (\$50) is assessed in misdemeanor and felony convictions. These mandatory sanctions are not popular with judges or attorneys. As a defense attorney in upstate New York explained,

I think that it's just plain stupid for the most part because it's got these compulsory surcharges. And way, way back when they invented surcharges, it was a comically small amount of fee. It was almost nothing. Okay. And they used to probably give people more fines back then, but when times are tough and so when the judges realize that imposing a fine just doesn't make sense. And so, the legislature says, "We don't care what you think. You're going to impose our fine, and we're going to call them surcharge and we're going to say that we're going to use it for crime victims or something like that," but it all really just goes into the general fund for whatever other thing they want to spend our money on. And so, yeah, it's just a tax system, and it doesn't bear any relation to the reality of what happened in a particular case.

This sentiment was common among judges who nevertheless felt that it was their duty to impose the law, which specified and required the payment of a certain amount. Judges often stressed that the amounts were "mandatory," as one in Illinois explained: "We are powerless to waive them with one exception [very old or very long running cases]." A New York judge expressed a similar sentiment: "As the judge, um, I'm simply kinda following the rules of what it should be. So I don't know if there's much variation." Court actors often absolve themselves of any responsibility in this system by describing "their hands as tied" when it comes to monetary sanctions. However, judges would also stress that they were able to use their discretion in the amount of time allowed for payment, which was intended to minimize the burden of these mandatory sanctions.

Mandatory surcharges set firm parameters around at least one aspect of sentencing. Judges had to impose these monetary sanctions, even if they were not fond of doing so. Judges who were attuned to the hardship some people had in paying them would reclaim some discretion in the domain of time. They could not waive certain sanctions, but they could adjust the time people had to pay. This transfer in judicial authority from money to time is a cornerstone in the foundation of procedural integrity.

\section{Concern with Efficiency and High Caseloads}

In both New York and Illinois, judges were concerned with the efficiency of case processing in light of perpetually high caseloads. Courtrooms often heard a large number of cases in one session-typically averaging a minute or less for each case. Notably, though, this rapid processing was most characteristic of courtrooms handling lower-level cases (vehicle and traffic offenses, misdemeanors, violations), where discussion of monetary sanctions was more frequent. Substantial time was spent scheduling continuances and payment hear- 
ings. In these lower-level courtrooms, across both Illinois and New York, courtroom workgroups rapidly churned through cases.

For example, in an upstate small city court in New York, we observed a financial hardship docket. The cases progress quickly regardless of whether the defendant is in the room. The judge moved swiftly through the first batch of cases, in which no defendant was present. Each case took a minute or less. The judge read the status of the case and his decision into the record in an empty courtroom. A summary of the judge's comments during the first seven cases taking place between 1:06 and 1:11 p.m. is as follows:

Defendant promised he would have it paid off in May; owes $\$ 94$, bail set at $\$ 100 / \$ 200$ [arrest warrant issued].

Defendant told me she'd be paying $\$ 50 /$ month and now she's not here; bail set at $\$ 300 / \$ 600$.

Defendant owes $\$ 795$; he is making payments; has been indicted on class D felony; enter civil judgment for fine and surcharge.

She's not here and she hasn't paid a dime, so we'll issue a warrant; bail set at $\$ 300 / \$ 600$.

Defendant is supposed to be paying $\$ 50 /$ month "didn't pay a dime" "and she's not here, so bench warrant" bail set at \$250/\$500.

Judge says "again no payments" he's not here; "so I'll issue a bench warrant."

Defendant owes \$438 didn’t pay a dime; so it's a bench warrant, no payment; bail $\$ 450 / \$ 900$.

This five-minute snippet of the court proceedings reveals the factors the judge considered important to put on the record: the defendant's payment history, the terms of the payment plan the defendant agreed to (time and amount), whether the defendant is present, and whether a warrant is being issued. Even when no defendant is present, the judge emphasizes compliance by noting whether anything has been paid. Similarly, in Illinois, bail amounts for failing to appear for payment review hearings were set at the total amount of outstanding fines and fees. This context of high caseloads and the desire for efficient, speedy processing is important to keep in mind as we assess judges' role in choreographing prolonged demonstrations of accountability on the part of defendants who have unpaid monetary sanctions.

Judges also made explicit the connections between people's failure to pay and concerns over the efficiency of the court. In one case lasting less than four minutes, we observed the judge say this: "Mr. F_, the only reason you're here is money. The only sentence I gave you was the minimum fine and surcharge and you still owe $\$ 258$. . . Y You made a payment yesterday, which reduced it to $\$ 83 . .$. I need to know what's gonna happen with the balance.... It's been three years, it's embarrassing. If you don't pay it, you're going to go to jail. I see all the notes and all the promises you made. I'm not messing around. . . . No reminders, that's it. ... You pay it by $8 / 31$ [four weeks from day of hearing] or that's it."

At the same time that he declares a threeyear payment period "embarrassing," he also emphasizes that he gave the defendant the minimum fine, an amount over which the court has little control. It is not entirely clear who is experiencing embarrassment, however. Is it the defendant, who should have paid more quickly? Or is it the judge and the court who should have enforced collection more harshly to prevent such a delay? The ambiguity is worth noting because it simultaneously conveys external pressure and a lack of compliance. The judge also invokes the defendant's responsibility and accountability by referencing "all the notes and all the promises [the defendant] made." Our observations revealed how the court must continue to encourage such payment hearingseven when the ability to pay is incredibly limited-to preserve the procedural integrity of the court proceedings. However, these small hearings exacerbated the court's overwhelming caseloads and impinged on its ability to process individuals quickly out of the system.

Tying the behavior of the defendant to the functioning of the court reflects the role of judges in implementing criminal justice policy. They are the pivot point between the demands of a large public institution and the financial realities of the people encountering that institution. 
Judges in Illinois appeared to prefer bringing defendants back for short payment hearings and spreading the payment out over time. They often suggested payment plans or were flexible about how many hearings it would take to pay off the balance. Judges were continually frustrated with the increasing legislatureimposed monetary sanctions but also held a strong moral commitment to avoid establishing "debtors' prisons," avoiding using incarceration as a consequence for nonpayment. A judge in a rural community in downstate Illinois described the situation this way: "The court system is strained because of compliance court requirements that the payments be monitored, so the judge and the prosecutor and the clerk have to come back to court again, and again, and again, to monitor compliance by individuals who are ordered to pay money that no one believes they have the ability to pay, and that no one believes they should have been ordered to pay, except for ... I'm going to stop there." This process often went on for years and it was not uncommon for us to observe cases that were from five or ten years prior. The judge later described this as the "transactional costs of this revenue-enhancing mechanism that has become the State of Illinois legislature." Here, we observed the balance of the court's desire to collect payment at the expense of efficiency. Although more payment hearings were preferred because of the lack of online payment options in many jurisdictions, these payments hearings subsequently filled many court dockets.

Altogether, we find general concern with the passage of time related to how long it takes a person to pay monetary sanctions in their entirety. Even as judges play their part in holding people accountable, the reality of recalcitrant or, more often, impoverished defendants thwarts their capacity to do so expeditiously. Instead, judges can enforce attendance at court, even if the result is years of hearings related to unpaid monetary sanctions. In this way, procedural integrity is upheld, even in the absence of significant progress toward successful payment.

\section{Interpersonal Dynamics}

Assessment of what transpires between people in the courtroom is key to understanding how contextual factors influence decisions made in court.

\section{Workgroups}

In both states, we observed stability in terms of courtroom workgroups. We noted indications of familiarity involving judges, clerks, bailiffs, attorneys, probation officers, and even defendants in some cases. In our field notes, for example, we recorded instances of court professionals inquiring about one another's children, house remodeling projects, and other personal details. Members of the workgroups would occasionally hug when first seeing each other or exclaim in apparent delight when seeing someone they had not seen in a while (see also Kirk et al. 2022, this volume).

In the urban courtrooms we observed are hundreds of judges and hundreds of state's attorneys and public defenders. These actors, however, tend to be consistently assigned to the same courtroom or set of courtrooms. This means that even in a city and criminal justice system as large as Chicago's or New York's, the assistant state's attorney, public defender, clerk, and judge tend to know each other well and work together each day. These appointments were fairly stable over the months we spent observing cases.

In smaller New York counties, the stability of the workgroups was even more pronounced, some counties having just a few judges in all. In smaller Illinois counties, typically at least one of each court actor would be permanently assigned. In both states, the working groups tended to be very stable over the course of many, many years. A rural probation officer in Illinois exemplifies the level of familiarity and stability in the courtroom workgroup:

I think because we're a closer-knit county, pretty much everybody ... Our former state's attorney was here for twenty-seven years, so he knew, basically, everybody in the county. Our sheriff, he's a hometown guy. He's been the sheriff, I think, this is going into his third or fourth term. Before that he was the chief of police, so he knows a lot of people. Our new state's attorney, he's from this area, so a lot of our people.... Our judge is from this area. A lot of our people are right here from 
A__ County. It's not people coming in from other counties or were not born and raised here. All of ... Our state's attorney, our judges, they were born and raised here. Everybody that works in this office, probation, was born and raised here, so it's a lot of ... Us, that work in the court system, we're from this area and we, pretty much, all of us together know everybody. I think that makes A_ County a little bit unique.

Although the speaker characterizes the county where he works as unique for having a long history of people knowing each other, we actually found this to be the case in most of our jurisdictions. Such familiarity speaks to the incentive people have to maintain good working relationships with each other, perhaps leading them to prioritize those relationships over the needs of any specific case (see also Kirk et al. 2022 , this volume). As one rural defense attorney in Illinois explained, "Oh yeah. If you get mad at an assistant state's attorney, and really get mad at them, the next time you want to negotiate something, they're going to remember that. They're going to say, 'Well, I'm not giving you anything. I'm not going to give you any offers. Heck with you.' That happens. Most of the assistant state's attorneys, I'd have to say, are well treated by private attorneys."

We also find evidence that people owing money to the courts become familiar to the workgroup because of repeated visits to court to make payments. An Illinois attorney explained it this way: "And you're back into the treadmill of trying to get out of jail, trying to get your stuff done. It goes over and over. But yeah lots of people that get caught up in all these little fees and costs and they can never get out or it takes them years, I mean years and years and years. We know them like their personal friends now. 'How you've been? How's your family? Is your son in school?' Stuff like that."

The stability of the workgroups and the repeated court appearances of defendants create situations that generate significant familiarity between people, regardless of their specific role in the proceedings and regardless of the size of the court.

The implications of the workgroup for man- aging payment of monetary sanctions are twofold. For one, evidence of familiarity within workgroups and the acknowledgment of the incentive to maintain good will highlight the parameters within which decision-making occurs. Similar to the pressures of case processing, the social pressure to conform to the norms of the court influences how monetary sanctions are handled. Second, workgroups are the mechanism that produce adherence to procedural integrity. In this way, the standards for how cases proceed are mutually influential with the people who process the cases. One is not separable from the other.

\section{Going Rate}

A number of factors influence the going rate for monetary sanctions and how they are handled post-sentencing. One factor is the interplay between mandatory surcharges and discretionary fines. As explained earlier, state-imposed mandatory surcharges are the predominant monetary sanction in both Illinois and New York. Judges assess a mandatory surcharge, cost, or assessment for nearly every case-traffic, misdemeanor, and felony, with exceedingly rare exceptions. DUIs and other violations of traffic and vehicle statutes tend to garner the largest mandatory sanctions. However, judges in our data do not typically assess discretionary fines, but when they do it tends to be closer to the minimum allowed by statute rather than the maximum. An attorney in New York explained: "In practice, the judges here don't impose any fines that aren't required. That is to say if no fine is required, they usually don't impose a fine."

Another factor influencing the going rate is how the workgroup interprets the oftenconvoluted statutes related to monetary sanctions. In Illinois, we noted significant confusion at the county level as to which fees were truly mandatory and when. This led to strong going-rate dynamics within counties where court actors used consistent amounts across types of cases. Often the going rate was higher in rural and suburban counties than in Chicago and Cook County. Court actors often told us that these amounts were mandatory (despite the slight variation we observed) and believed the amounts to be legislatively imposed. 
In New York and Illinois, monetary sanctions rarely serve as an alternative to punishment, but more often instead as one piece of a list of sanctions that can include jail time, mandatory treatment, community service, and other programming. Failing to complete these other requirements can lead to supervision violations or additional status hearings, but in both states none gave rise to as many court hearings as monetary sanctions. This was often the result of defendants entering into payment plans with the court that either required frequent appearances in court to make payments or required court appearances to explain why payment in full continued to be impossible.

That is, our evidence supports the extension of going rates to payment plans. For people who were struggling to pay (and therefore had repeated court appearances), judges in both states would typically ask whether they could pay between $\$ 25$ and $\$ 50$ a month. Maintaining the appearance of effort, however, could require as little as $\$ 5$ or $\$ 10$. By engaging in activities deemed meritorious for reflecting personal accountability (such as repeated court appearances, contrition, minimal sporadic payments, and so on), defendants can engender leniency in the enforcement of monetary sanction payment. In this way, procedural integrity demands time more than money.

\section{Nonpayment and Consequences}

At the same time that the court's mandate is to ensure "equality and uniformity before the law," the vast majority of people who come through the criminal court system are impoverished and otherwise marginalized and lacking in social capital. This tension between the macro myth of the court's ethos and the court's everyday reality proves to be fertile ground for treating both time and money as valuable resources. As we explored the management of post-sentencing payment, a few themes emerged. We find evidence of negotiation between judges and defendants as well as a preponderance of minimal sporadic payments. In these repeated contacts between defendants and court actors, a performative aspect of the interactions became clear, as did the specific roles of compliance and contrition.

\section{Negotiation}

The literature on criminal sentencing often focuses on the discretion or interaction of judges and prosecutors (Kim, Spohn, and Hedberg 2015). But with post-sentencing enforcement of monetary sanctions, the negotiation of payment happens between the judge and the defendant. Legal counsel was only sporadically present in the cases we observed. A dialogue of negotiating the portion of the monetary sanctions that corresponds to time rather than negotiating the amount or searching for solutions to payment was a common occurrence in our observations. Frequently, defendants would report that they were unable to pay anything on a given day due to job loss or unemployment, other outstanding debts, or unexpected financial responsibilities. "I need more time" was a frequent refrain and the judges we observed frequently granted the extension (Pattillo and Kirk 2021).

We conceptualize this dynamic as a trade-off in terms of the use of time in light of functionally unpayable financial punishment. As long as defendants expressed or demonstrated the effort of payment by appearing before the court, by requesting more time, and by providing a plausible story as to their nonpayment, the court granted additional time to pay. This shift in negotiation reveals how judges interpret their role in implementing a component of criminal justice policy. They may be statutorily limited in what monetary sanctions they must impose, but judges have wide discretion over the period in which payment occurs. Time therefore becomes a tool implemented in pursuit of procedural integrity.

A good example of the type of exchange we observed occurred in a case involving a man who had been charged with possessing fifteen grams of cannabis, which had been found during a probable cause search, which in turn are notoriously subject to police discretion. The hearing lasted less than five minutes. Here the judge seems to be taking into consideration the defendant's stance prior to sentencing as well as after.

JUDGE: "All right, is [First and Last Name of Defendant] here? Why don't you come on up sir?"

DEFENDANT approaches defense lectern. 
JUDGE: "Now that you've had two weeks to think about it, what do you wish to do?"

DEFENDANT: “ I don't believe I should've been pulled over in the first place." The defendant then attempts to explain his rationale and that he is pleading guilty because this is his third time in court. The judge issues a sentence that includes a $\$ 75$ fine and a \$120 surcharge, saying "I have nothing to do with [the surcharge]. I can't waive it."

JUDGE: "I do need to know when you can pay the state of New York \$195, which you do owe ... I can work with you on that." The defendant agrees to pay $\$ 100$ that day then the remaining \$95 within two months. The judge explains the financial hardship hearings, saying that "your one chance to let us know [about financial hardship] is September 28th" [two months later]. The judge goes on to say that "if you can't pay ... then a lot of bad things can happen," which includes "a warrant for your arrest, a civil judgment."

This exchange illuminates how discussions of payment open the door for judges to tailor the payment terms to a person's circumstance. It also shows how the backdrop of mandatory surcharges limits discretion as well as the judge's need to justify his decision, given that he can and does point to the state of New York as the recipient of the funds.

The reconviction phase of the criminal legal process is designed to be adversarial and has been shown to constitute its own form of punishment (Feeley 1979). However, postsentencing and in the realm of monetary sanctions, a different dynamic emerges. Defendants are in position to have input into the terms of payment and this input is given directly to the judge. Often, no attorney is present. The negotiation within the judge-defendant dyad is a constitutive element of procedural integrity. This negotiation facilitates successful payment, insofar as defendants can and do accurately assess their ability to meet the payment terms. It thus helps fuel ongoing contact with the courts.

\section{Minimal Sporadic Payments}

A strong connection between the exigencies of court and the lack of financial resources of peo- ple with a criminal conviction exists in the ubiquity of minimal sporadic payments. At the same time that the court seeks to hold people accountable, people have limited means with which to satisfy their financial sentence. The result is that some end up coming to court repeatedly to make small payments on what they owe. Small payments of $\$ 10$ or $\$ 15$ were frequent in Illinois even if the outstanding balance was much larger, as was the case with a defendant we observed in a suburban Illinois court who was charged $\$ 23,371$ and made a $\$ 100$ payment. A few examples from our field notes capture the practice:

Each time the judge also asked how much people could pay and most people could pay small amounts ranging from $\$ 15$ to 50 , but many also said they couldn't pay anything at the moment.

Next was a Black man in his forties. He was paying \$30 today. The judge asked him, "Do you want to come back in one more or two?"

NY clerk instructed a defendant to make a payment of at least \$20, "you need to pay something."

This demonstration of effort was important to court actors. Court actors described wanting to see defendants "do the work" in these shows of compliance. This work often did not mean that defendants actually had to repay their court-ordered debt. Instead, it meant a standard trade-off of time- of coming to court, appearing, and stating one's case. For instance, we observed an interaction between a public defender and a female defendant in Illinois. "He asked if she had 'made any progress.' She said she paid \$10 a month. She said she was a single mother and it was hard. That's all she could do. He said that's all they needed to see, that she was trying and making an effort." Her appearance, the time and effort she was putting into the impossible task of paying off this debt functioned as a signal to the court, both as a punishment in itself and a delaying of possible additional punishment due to nonpayment.

Court professionals are also aware of the practice and even have nicknames for it. As an 
Illinois attorney explained, "I mean I've seen in Union County, which is north of here, the first Friday of every month is, they call it a 'pay and repair' day. And these people who have not paid their fines and costs come in and give an accounting of themselves. I hate to say this but for a lot of the individuals that show up, they'll walk in and pay five dollars and think that's enough to keep them from getting into further trouble with the court."

Court professionals also acknowledge the burden these small, regular payments may be: "I've got people who come in and pay $\$ 5$ a month, that means something when you're listening to somebody say they could pay zero a month. There are people who try and the trying means something, which means the lack of trying has to mean something so that the people who are trying knows it matters. You're aware, you're aware that it's an impact."

These minimal sporadic payments illuminate how people who cannot pay in full and on time become tethered to the courts. They also show a certain awareness of the futility of pursuing these payments on the part of the courts, constrained as they are by the law and local norms. In pursuing the ideal of accountability for all, judges insist on payment. In reckoning with the poverty of many people with criminal convictions, judges allow flexibility in payment. If people do not have money to pay, they must spend time. This trade-off between time and money is essential to procedural integrity. It echoes the dynamics of the going rate and the statutory constraints: discretion emerges where it can.

\section{Compliance and Contrition}

Demonstration of the proper behavior and affect are key components of what procedural integrity demands of defendants. The norms of the court required not only how time is spent inside and outside court but also certain displays of deference to the court's authority, including compliance and contrition (see Heubner and Shannon 2022, this volume). Such displays illuminate the experiential aspects of going through a system where, due to the macro myth explained, fidelity to case processing overshadows payment of monetary sanctions.
Because defendants' socioeconomic circumstances often precluded them from meeting their legal financial obligations, the court had to rely on other indicators of deference to assess the individuals' compliance and thus to determine what kind of treatment they deserved. Two essential criteria were how consistently defendants appeared for their scheduled hearings and the degree to which they abided by court customs and expectations of behavior. Defendants who failed both to comply with the terms of payment and to appear in court were subject to firm disapproval. A good example is the response of a judge in an upstate New York city to a defendant's record of failing to appear: "First of all, you need a license. Second of all, oh my goodness, looks like you come and go as you please!" She took an admonishing tone with him and asked about his paying anything. The judge then noted, "The People are ready to declare on two PL [penal law] charges" and he needed to get a license, "but you don't like to show up." She continued, "If you show up, I won't put bail on you." She instructed him to "pay off one at a time" with directions about where and how to pay ("next door" at city hall). She also noted, "These are all failure to appear summonses.... You need to pay something!" Similarly, defendants were reprimanded for not behaving appropriately in court and were often forced to spend additional time waiting to have their case called. This occurred with a defendant we observed in Illinois who looked tired and was falling asleep while he waited. The judge became annoyed and postponed his hearing further, to the end of the court call that morning. We again observed this kind of dynamic in an urban New York courtroom when a judge explained, "I've said it before and I'll say it again. Let's not see any more phones. The way we have to enforce it is to move your file to the very back of the line. So you'll be here a very long time." Thus the court both rewarded defendants who complied and punished those who did not conform to the rules.

Cooperation with the court's efforts to orchestrate procedural integrity-making all scheduled hearings, appearing to give one's time freely and without frustration or complaint-meant those defendants received more flexibility in scheduling, while avoiding addi- 
tional punishment. Yet, despite such flexibility on the part of judges, this additional imposition of extending time and additional demands on defendants' time does not necessarily lessen the punishment enacted by this process, and can actually exacerbate it. Moreover, these frequent appearances and routinization of payment turn the court into a debt collector, a coercive financialization that commodifies freedom and amplifies control over the individual (Pattillo and Kirk 2021). Affective displays of remorse were another way defendants performed and court actors assessed deference to authority and procedure. During our observations, we occasionally noted overt demonstrations of contrition by defendants or acknowledgments of it by judges and attorneys. These instances took place almost exclusively in sentencing hearings. Sentencing allows judges a forum in which they can hold forth on social norms and values, as well as normative assessments of the defendant. We observed some judges making statements about defendants having learned their lesson (or not); such utterances implicitly endorsed the view that criminal sanctions are intended to change the individual into a more prosocial version of him or herself.

Although sincere contrition may evoke sympathy and even leniency, the opposite also appears to be true. That is, court actors may adopt a more hardline stance with a defendant if they perceive the individual as insufficiently remorseful. Illustrating this point were two county court cases observed in rural upstate New York. In the first, a man who the judge described as a "second violent felony offender" faced sentencing for a second-degree attempted robbery conviction. Throughout sentencing, the judge made clear his displeasure and disappointment with the defendant, whom he viewed as failing to accept responsibility for his actions and express remorse. The observing researcher noted the following comments that the judge directed at the defendant: "You are on extraordinarily thin ice at this point" (followed by a warning that his next felony conviction would result in a life sentence). "If I were to make a prediction, you're gonna be back in no time." "You are a menace to society and you're learning nothing through all this." "You took no responsibility for your actions." "That's why we have predicate offender laws." The judge then imposed a five-year minimum sentence with five years of post-release supervision, plus restitution and a collection fee. He concluded, "Good luck. I hope you make use of your time, but I don't hold out a lot of hope."

Defendants who fulfilled the court's expectations neither in terms of compliance behaviors nor in their affective performance were particularly likely targets for castigation. Take, for instance, a hearing we observed in an upstate New York court for an individual convicted of an A Misdemeanor. This defendant, who had long-standing unpaid monetary sanctions, owed restitution, and apparently demonstrated inappropriate affect, induced an outraged articulation of the court's norms around payment and behavior:

"You've owed this money for not 1, not 2, but 3 years." "It's not fines or surcharges ... it's money you owe the victim of your crime." "This is why it's embarrassing" "you told me you would pay $\$ 50$ a month." "Show me your credibility and you completely failed." FTA [failure to appear], so issued a warrant; defendant phoned in a day late. $\mathrm{D}_{\text {_ }}$ has posted money for your case. "Now we're on the 3rd change and that's why you're smiling." "No, I'm not smiling." "Now you're showing up late." "Why shouldn't I send you to jail today?" "Ok, I will." "You need time to bond with your attorney to look in the mirror and ask yourself what's going on with your life." "You still owe this money. You haven't paid a dime." "You admit the violation of your restitution." $D e$ fendant explains not smiling, biting his lip because torn ACS, pulls down neck of $t$-shirt to show shoulder. "How do you intend to make this right with the criminal justice system." "I want to hear a blueprint for how you are going to handle this." "It's been three years and it's embarrassing." Defendant taken to jail.

By contrast, expressions of remorse combined with demonstrated efforts to comply with court orders evoked more positive responses from judges and other court actors, both substantively and in terms of affect. A felony court 
judge in the Bronx, for instance, praised a defendant for progress he had made. Reviewing the presentencing report, he remarked that the young man had engaged in programming and was currently testing negative for all drug use. "He became gainfully employed . . . engaged in attending class for his GED equivalency." "Congratulations, young man ... you make coming here everyday worthwhile." The judge then characterized the offense as a lapse in judgment, noting that the defendant admitted guilt and expressed remorse. The young man would still be responsible for the mandatory surcharge, but having the charges reduced (and being adjudicated as a "youthful offender") such that he would end up with no criminal record, perhaps allowed the defendant to avoid a more serious conviction and the attendant monetary sanctions, along with the secondorder effects of a criminal record on his longterm financial capacity. Further demonstrating the sympathetic attitude and with which the judge regarded this defendant, he wrapped up the hearing on a friendly, familiar note, making a joke about how he and the defendant rooted for rival baseball teams.

The extent to which remorse mattered hinged on whether others deemed the defendant to be genuine in their statements and affect. Scholars examining the impact of remorse on judicial decision-making indicate that apologizing can backfire on defendants if court actors perceive them as inauthentic. Moreover, judges may be apt to dismiss most apologies as driven by instrumental aims (Rachlinski, Guthrie, and Wistrich 2013). When defendants made statements of intent-for instance, saying they wanted to do better and comply with their legal obligations - the court had to then determine whether it could take them at their word. Whether the court ends up regarding remorse as a mitigating factor is contingent on whether the court viewed them as sincere. Demonstrable compliance efforts, more than just verbal statements about a defendant's intention to comply, were held up as evidence of sinceritythat they were truly doing all they could to satisfy the court's orders, even if those efforts fell short of what was required of them. For example, a judge in an upstate New York city explained that she needed documented proof of a defendant's program participation: "I'm not going to just take you at your word, no offense." Taken together, we see that defendants' role in the performance of procedural integrity involves certain behaviors and affective displays that in combination signal deference to the court's authority.

\section{DISCUSSION}

Procedural integrity characterizes postsentencing management of monetary sanctions in New York and Illinois, in light of the limited successful collection of these funds. Judges, in particular, required defendants to perform their compliance with the process of appearing in court even when collection of the fines and fees was likely impossible. In both places, circumstances conspire to emphasize the display of fidelity to the process in the absence of widespread ability to quickly pay monetary sanctions. Indeed, we observed the fairly universal granting of additional time for nonpayment and the avoidance of punishment for nonpayment alone.

Judges and courtroom workgroups face external constraints and pressures that shape how monetary sanctions are imposed and collected. Surcharges are mandatory even though many defendants cannot afford to pay them. Although judges lack discretion in these two states around imposing surcharges, they have nearly complete control over the collection process and the incentives or penalties for nonpayment. Jail is used as a threat to compel payment rather than as a punishment for nonpayment. As a result, demands are placed on people's time in terms of coming to court repeatedly and staying in court far longer than the duration of any given hearing. In this way, the extraction of time and the compliance performance of good faith and contrition is the punishment expected of defendants who are unable to pay.

Taken together, these factors of time, emphasizing the risk of jail, and setting expectations for behavior constitute the going rate for the adjudication of post-sentencing monetary sanctions. The external pressures to maximize efficiency are important context for understanding how courtroom workgroups navigate the space between the dominance of mandatory surcharges and the widespread difficulty 
people have in paying what they owe. The courtroom workgroups we observed tend to settle into more or less a template of how payment is handled over the long term (Ulmer 2019).

Our findings reveal how factors such as the stability of courtroom workgroups couple with the familiarity of defendants coming to court to enable negotiation about payment amounts and schedules. Such negotiations reflect postsentencing assessments of a defendant's deservingness of leniency, reframing the idea of blameworthiness. In discussions with court actors in both states, the conviction was strong that people should not be punished for their poverty. Comments about the abolishment or avoidance of debtors' prisons were common. The lack of proportionality in imposing monetary sanctions in both states inevitably leads to this dynamic. To reconcile these conflicting values of the court, we observe judges reframing what it meant to fulfill the court's demands. Instead of blameworthiness being about the type and amount of monetary sanction a person's actions warrants, it is about the extent to which someone complies with the court's demands on their time and behavior. The assessment of blameworthiness allows room for acknowledging difficult life circumstances, which in our observations makes a person less to blame for lack of compliance on either front.

The macro myth undergirding court operations in general is that everyone is equally responsible for paying what they owe despite an unequal ability to pay. April Fernandes, Brittany Friedman, and Gabriela Kirk (2022, this volume) describe how nonpayment is often construed as willful, tied to a moral and social responsibility to the state to pay for the services it provides. Particularly in considering the amount of time and flexibility given for payment, court actors feel justified in punishing defendants for noncompliance when it occurs. However, doing so ignores the enduring and insurmountable difficulty some defendants face in putting aside the amount of money needed to resolve their cases.

Our observations connect with some of Malcolm Feeley's (1979) key findings about the arduous path people take to having their cases adjudicated. Feeley focused on the punitive na- ture of the pretrial process. Our results illuminate the punitive aspects of the post-sentencing process related to monetary sanctions. In both phases, legal representation can be sparse. Also like Feeley, we find that cases can transpire over long periods, even though individual hearings are often brief and defendants may be confused about the process.

We add to this work and the long lineage of scholarship it spurred with an assessment of post-adjudication costs-primarily in terms of time, stress, and performativity on the part of the defendant. In addition, our findings about the going rate for time and money postsentencing relate to Feeley's notion of case worth. Feeley observed how interactions between the defense attorney and the prosecutor produced a shared sense of how factors such as the framing of people and situations, as well as which aspects of a case were discussed or ignored, were integral to the resulting plea agreement. By comparison, we observe how courtroom workgroups (but especially judges) construe defendants' behavior in and out of court to determine acceptable parameters for payment. Consistent with the notion of the process being punitive, our findings support the conclusion that a procedurally just system does not necessarily produce substantively just outcomes. Although court actors recognize that monetary sanctions may not result in a fair punishment depending on an individual's ability to pay, they feel little responsibility for ensuring that payment systems and procedures do not lead to additional punishment. However, as this article and others in this issue have established, both the amounts imposed and the collection processes that follow lead to the perpetuation of inequality in this system (see, for example, in this volume, Sykes et al. 2022; Pattillo et al. 2022; Bing, Pettit, and Slavinsky 2022).

\section{CONCLUSION}

In describing the equilibrium reached by the countervailing forces of case processing pressure, mandatory monetary sanctions, defendants with pronounced financial insecurity, and judicial discretion, we shed new light on the role monetary sanctions play in how courts function. The crux of this equilibrium is com- 
pelling defendants to adhere to procedural integrity in the absence of monetary sanctions paid fully and quickly.

We have explored how external factors interact with courtroom decision-making in the confrontation of unpaid court-ordered debt as an individual reality. Our findings about how time is used in the adjudication of monetary sanctions suggest previously unexamined connections between the strictures of the legalbureaucratic conditions in which courts operate and courts' demand for demonstrations of accountability on the part of defendants. Our data shed light on the realities of how workgroups constantly navigate the terrain where formal rules and laws meet informal norms and shared perceptions. We have shown how the "constitutive rules and taken-for-granted practices" that workgroups use manage the uncertainty about the likelihood of a person successfully paying their monetary sanctions and keep the machinery of the courthouse running (Ulmer 2019, 511). We also expose a gray area between procedural and substantive justice in which fidelity to a fair but prolonged process has elements of both leniency and punishment. In the process, we reveal how people with unpaid monetary sanctions demonstrate an ability to endure the tests of the process, thereby attesting to their acquiescence as an offset to their blameworthiness.

Overall, by recognizing the value of time in adjudicating money-based punishment, this analysis deepens our understanding of how court actors navigate both while enriching our knowledge about case processing more generally. An emphasis on procedural integrity emerges from the interplay of sociolegal context and interpersonal dynamics. This insight can serve as a fruitful point of departure for future work on the practicalities involved in the pursuit of justice, where money matters and time is of the essence.

\section{REFERENCES}

Bandes, Susan A. 2016a. "Remorse and Criminal Justice." Emotion Review 8(1): 14-19.

_. 2016b. "Remorse and Demeanor in the Courtroom: Cognitive Science and the Evaluation of Contrition." In The Integrity of the Criminal Pro- cess, edited by Jill Hunter, Paul Roberts, and Simon Young. Portland, Ore.: Hart Publishing.

Bing, Lindsay, Becky Pettit, and Ilya Slavinski. 2022. “Incomparable Punishments: How Economic Inequality Contributes to the Disparate Impact of Legal Fines and Fees." RSF: The Russell Sage Foundation Journal of the Social Sciences 8(2): 118-36. DOI: https://doi.org/10.7758/RSF.2022 8.2.06.

Cadigan, Michele, and Gabriela Kirk. 2020. “On Thin Ice: Bureaucratic Processes of Monetary Sanctions and Job Insecurity." RSF: The Russell Sage Foundation Journal of the Social Sciences 6(1): 113-31. DOI: https://doi.org/10.7758/RSF.2020 6.1.05.

Eisenstein, James, Roy B. Flemming, and Peter F. Nardulli. 1988. The Contours of Justice: Communities and Their Courts. Boston, Mass.: Little, Brown.

Feeley, Malcolm M. 1979. The Process Is the Punishment: Handling Cases in a Lower Criminal Court. New York: Russell Sage Foundation.

Fernandes, April D., Brittany Friedman, and Gabriela Kirk. 2022. “The 'Damaged' State vs. the 'Willful' Nonpayer: Pay-to-Stay and the Social Construction of Damage, Harm, and Moral Responsibility in a Rent-Seeking Society." RSF: The Russell Sage Foundation Journal of the Social Sciences 8(1): 82-105. DOI: https://doi.org/10.7758/RSF .2022.8.1.04.

Friedman, Brittany, and Mary Pattillo. 2019. “Statutory Inequality: The Logics of Monetary Sanctions in State Law." RSF: The Russell Sage Foundation Journal of the Social Sciences 5(1): 174-96. DOI: https://doi.org/10.7758/RSF.2019.5.1.08.

Harris, Alexes, Mary Pattillo, and Bryan L. Sykes. 2022. "Studying the System of Monetary Sanctions." RSF: The Russell Sage Foundation Journal of the Social Sciences 8(1): 1-33. DOI: https://doi. org/10.7758/RSF.2022.8.1.01.

Huebner, Beth M., and Andrea Giuffre. 2022. "Reinforcing the Web of Municipal Courts: Evidence and Implications Post-Ferguson." RSF: The Russell Sage Foundation Journal of the Social Sciences 8(1): 108-27. DOI: https://doi.org/10.7758 /RSF.2022.8.1.05.

Huebner, Beth M., and Sarah K.S. Shannon. 2022. “Private Probation Costs, Compliance, and the Proportionality of Punishment: Evidence from Georgia and Missouri." RSF: The Russell Sage 
Foundation Journal of the Social Sciences 8(1): 179-99. DOI: https://doi.org/10.7758/RSF.2022 8.1.08.

Kim, Byungbae, Cassia Spohn, and E. C. Hedberg. 2015. “Federal Sentencing as a Complex Collaborative Process: Judges, Prosecutors, JudgeProsecutor Dyads, and Disparity in Sentencing." Criminology 53(4): 597-623.

Kirk, Gabriela, Kristina Thompson, Beth M. Huebner, Christopher Uggen, and Sarah K.S. Shannon. 2022. "Justice by Geography: The Role of Monetary Sanctions Across Communities." RSF: The Russell Sage Foundation Journal of the Social Sciences 8(1): 200-220. DOI: https://doi.org/10 .7758/RSF.2022.8.1.09.

Kohler-Hausmann, Issa. 2018. Misdemeanorland. Princeton, N.J.: Princeton University Press.

Lynch, Mona. 2019. “Focally Concerned About Focal Concerns: A Conceptual and Methodological Critique of Sentencing Disparities Research." Justice Quarterly 36(7): 1148-75.

Pattillo, Mary, Erica Banks, Brian Sargent, and Daniel J. Boches. 2022. "Monetary Sanctions and Housing Instability." RSF: The Russell Sage Foundation Journal of the Social Sciences 8(2): 57-75. DOI: https://doi.org/10.7758/RSF.2022 8.2.03.

Pattillo, Mary, and Gabriela Kirk. 2021. “Layaway Freedom: Coercive Financialization in the Criminal Legal System." American Journal of Sociology 126(4): 889-930.

Rachlinski, Jeffrey J., Chris Guthrie, and Andrew J. Wistrich. 2013. "Contrition in the Courtroom: Do Apologies Affect Adjudication." Cornell Law Review 98(5): 1189-1244.

Slavinski, Ilya, and Kimberly Spencer-Suarez. 2021. "The Price of Poverty: Policy Implications of the
Unequal Effects of Monetary Sanctions on the Poor." Journal of Contemporary Criminal Justice 37(1): 45-65.

Smith, Tyler, Kristina J. Thompson, and Michele Cadigan. 2022. "Sensemaking in the Legal System: A Comparative Case Study of Changes to Monetary Sanctions Laws." RSF: The Russell Sage Foundation Journal of the Social Sciences 8(1): 63-81. DOI: https://doi.org/10.7758/RSF.2022 8.1.03.

Steffensmeier, Darrell, Jeffery T. Ulmer, and John Kramer. 1998. "The Interaction of Race, Gender, and Age in Criminal Sentencing: The Punishment Cost of Being Young, Black, and Male." Criminology 36(4): 763-98.

Sudnow, David. 1965. “Normal Crimes: Sociological Features of the Penal Code in a Public Defender Office." Social Problems 12(3): 255-76.

Sykes, Bryan L., Meghan Ballard, Andrea Giuffre, Rebecca Goodsell, Daniela Kaiser, Vicente Celestino Mata, and Justin Sola. 2022. "Robbing Peter to Pay Paul: Public Assistance, Monetary Sanctions, and Financial Double-Dealings in America." RSF: The Russell Sage Foundation Journal of the Social Sciences 8(1): 148-78. DOI: https://doi .org/10.7758/RSF.2022.8.1.07.

Ulmer, Jeffery T. 2012. "Recent Developments and New Directions in Sentencing Research." Justice Quarterly 29(1): 1-40.

—. 2019. “Criminal Courts as Inhabited Institutions: Making Sense of Difference and Similarity in Sentencing." Crime and Justice 48(1): 483522.

Wood, Linda A., and Clare MacMartin. 2007. “Constructing Remorse: Judges' Sentencing Decisions in Child Sexual Assault Cases." Journal of Language and Social Psychology 26(4): 343-62. 